\title{
AN INFORMER'S TALE: ITS USE IN JUDICIAL AND ADMINISTRATIVE PROCEEDINGS
}

AN informer is one who voluntarily reports law violations or misconduct to an agent or official of the government. ${ }^{1}$ Informers' communications cover a wide variety of subjects. They most repeatedly involve liquor and narcotics law violations, larceny, vice, and illegal gambling. ${ }^{2}$ Reports of government employees" "disloyalty" and of antitrust and wage-hour law violations are also frequent. ${ }^{3}$ Communications from informers are received with varying frequency from four principal sources. Ordinary private citizens are the most prolific source. ${ }^{4}$ Less commonly information is received from one who has participated in a crime and subsequently turned against his partners. ${ }^{\circ}$ And occasionally information is received from a "plant" employed by a law enforcement agency to participate in the commission of a crime, ${ }^{b}$ or from one who seeks evidence of a crime with the approval or upon the urging of governmental authorities. ${ }^{7}$

1. Definitions of informers, narrower than the one chosen here, have been attempted. E.g., Bryant v. Skillman Hardware Co., 76 N.J.L. 45, 46, 69 Atl. 23, 24 (1908) (an informer is one who gives information of a crime in order to prosecute the offender); United States v. City of Mexico, 32 Fed. 105, 105 (S.D. Fla. 1887) (one whose information leads directly to a legal proceeding); Pollock v. Steam-Boat Laura, 5 Fed. 133, 141 (S.D.N.Y. 1880) (a person who lodges information with a government officer which leads to a suit by the government itself). However, these definitions are not susceptible of general application. When viewing the role of the informer in the entire law cnforcement process, the broader definition in the text is accurate.

2. Conclusion based on response to questionnaire distributed in 1953 by the YALE LAW JouRnac to 31 police departments in cities of 25,000 population or more, (hereinafter cited as Questionnaire). The following states are represented: Calif, Colo., Conn., Del., Fla., Ill., Ind., Iowa, Ky., La., Mich., Minn., Neb., N.J., N.C., N.D., Ohio, Texas, Utah, Va., Wash., and Wisc. Copies of the questionnaire and replies are in Yale Law Library. See Vollmer, The Police in Modern Society 47, 87, 110 (1936).

3. Disloyalty: Bailey v. Richardson, 182 F.2d 46 (D.C. Cir. 1950), aff'd by an cqually divided court, 341 U.S. 918 (1951); Deak v. Pace, 185 F.2d 997 (D.C. Cir. 1950).

Antitrust: United States v. Lorain Journal Co., 10 F.R.D. 487 (N.D. Ohio 1950); United States v. Sun Oil Co., 10 F.R.D. 448 (E.D. Pa. 1950); United States v. Deere $\&$ Co., 9 F.R.D. 523 (D. Minn. 1949) ; United States v. Kohler Co., 9 F.R.D. 289 (E.D. Pa. 1949).

Wage-Hour: Walling v. Richmond Screw Anchor Co., 4 F.R.D. 265 (E.D.N.Y. 1943) ; Fleming v. Bernardi, 1 F.R.D. 624 (N.D. Ohio 1941).

4. Qufstionnaire. Twenty-three police departments indicated that their most frequent source of confidential information is ordinary private citizens.

5. Ibid.

6. Ibid. See Hopkins, Our Lawless Police 104-109 (1931).

7. Questionnarre. See Hoover, A Comment on the Article "Loyalty Among Government Employees", 58 Y ALE L.J. 401, 404 (1949). 
The informer plays an important role in the enforcement of criminal, civil, and administrative laws. Law enforcement agencies-local, state, and national -carefully consider all informers' communications, and with the aid of such reports many law infractions are exposed. 8 The information received may prompt an investigation ${ }^{9}$ or be used as the basis of an arrest or search; ${ }^{10}$ ultimately, sufficient evidence may be gathered on which to base a successful criminal or civil action.11 And it is not unusual for an informer's communication to motivate and support proceedings before an administrative agency.12

However, supplying information to the government may involve danger to the informer. He may expose himself-and perhaps also his family and friends-to physical violence, social ostracism, or legal action. ${ }^{13}$ Fear of these consequences must be obviated if law enforcement authorities are to receive the information they consider so valuable. It is not enough to say that it is both the citizen's duty and his right to report law violations ;" many individuals will remain reluctant to give information to the government unless they are assured effective protection. ${ }^{15}$ Moreover, if the informer is engaged in counter-espionage, disclosure of his identity might endanger national security by jeopardizing the agent's future usefulness. ${ }^{16}$ As a result, law enforcement agencies frequently desire to withhold the source and contents of informers'

8. Questionnaire See Shafer v. State, 151 Tex. Crim. 558, 561, 209 S.W.2d 599, 602 (1948) ; State v. Viola, 51 Ohio Law Abstract 577, 586, \&2 N.E.2d 306, 313 (1947). See Elliott, Crime in Moderd Soctetr 490-1 (1952); Donnelly, Judicial Control of Informants, Spies, Stool Pigeons, and Agents Prococateurs, 60 YALE L.J. 1091 (1951); Comment, 22 CalIF. L. Rev. 667, 674 (1934). Cf. Statement of J. Edgar Hcover in Hearings before Senate Committee on Appropriations on Supplemental Appropriations for 1951, 81st Cong., 2d Sess. 740 (1950).

9. QuestionnaIRE. See United States v. Keown, 19 F. Supp. 639, 646 (IW.D. Ky. 1937).

10. See note 9 supra; HopkINs, op. cit. supra note 6 , at $\$ 9$.

11. QUESTIONNATRE.

12. See pp. 221-2 inifra.

13. See statement by August Vollmer quoted in Comment, 22 C.LLF. L. REv. 667, 676 (1934). See also Fusco v. Moses, 304 N.Y. 424, 433, 107 N.E.2d 581, 583 (1952); Note, 6 So. Calir. L. Rev. 245, 246 (1933).

A vivid illustration of the dangers to which informers may expose themselves is the Arnold Schuster murder case. Schuster's identification led to the arrest of bant: robber Willie Sutton. The New York police publicly disclosed that Schuster was the informant. A few days thereafter, Schuster was mysteriously slain. N.Y. Times, Feb. 21, 1952, p. 1, col. 2; id., March 9, 1952, p. 1, col. 8.

14. See Inz re Quarles \& Butler, 158 U.S. 532, 535 (1894).

15. See sources cited note $S$ supra; Statement of J. Edgar Hoover in Hcaris:gs ucforc Subcommittee of Committee on Forcign Relations on S. Res. 231, 81st Cong., $2 d$ Sess. 328 (1950). See also Trial of Thomas Hardy, 24 How. St. Tr. 199, 816 (1794). Cf. Hoover, Civil Liberties and Law Enforcenent: The Role of the F.B.I., 37 Iowa L. Rev. 175, 193 (1952).

16. See statement of Seth Richardson, Washington Post, Dec. 28, 1947, p. 10, cols. 3-8; Bontecou, The Federal Loyalty-Security Prograx 135, 246 (1953). Sce also Jacl:son, J., dissenting in Knauff v. Shaughnessy, 338 U.S. 537, 551 (1949). 
communications in courtroom and administrative proceedings. And they have persuaded the judiciary to devise positive policies implementing this desire.

To the extent that policies shielding informers do not impinge upon fundamental rights of others, they appear justified. But society has an interest in assuring fair play to the parties involved, as well as in efficient law enforcement.17 Under our system of government, sanction enforcement practices must adjust to civil liberties; efficiency does not substitute for the demands of justice. And while the guiding principle of fairness underlying judicial and administrative proceedings cannot be incorporated in an immutable formula, it requires at least that parties to a proceeding have full opportunity to meet the case against them. This opportunity may be obstructed by denial of a party's claim that knowledge of an informer's identity and a chance to cross-examine him is essential to his case. Moreover, unfairness results where a party is prevented from proving his case by being denied access to the contents of an informer's communication. And grave injustice occurs where the report of an unknown informant is utilized by a tribunal as evidence.

\section{The Informer in the Courtroon}

\section{Facilitating the Use of Informers}

Courts have developed evidentiary rules which facilitate the use of informers by law enforcement agencies. To encourage the communication of information to governmental authorities it is sometimes deemed necessary to suppress both the identity of the informer and the contents of his report.18 Some rules have developed which serve only one of these functions $;^{10}$ others serve both. ${ }^{20}$ Those rules which are designed to shroud the identity of informers are said to benefit the government, although incidentally they accommodate informers. ${ }^{21}$ And some rules protect from revelation the contents of an informer's communication, even after the informer's identity has been disclosed. ${ }^{22}$ These rules are designed primarily to benefit the informer ${ }^{23}$ they immunize him from actions for libel, slander, and malicious prosecution..$^{24}$

17. "Law enforcement, however, in defeating the criminal, must maintain inviolate the historic liberties of the individual. To turn back the criminal, yet, by doing so, destroy the dignity of the individual, would be a hollow victory." Hoover, Civil Libertics and Law Enforcement: The Role of the F.B.I., 37 Iowa L. Rev. 175, 177 (1952). Sce Douglas, Being AN Amrerican 108 (1948). Cf. Holmes, J., dissenting in Olmstead v. United States, 277 U.S. 438, 470 (1928).

18. See Sanford, Evidentiary Privileges against the Production of Data within the Control of Executive Departments, 3 VAND. L. REv. 73, 76 (1949).

19. See text at notes 39,42 infra.

20. See text at note 29 infra.

21. See Worthington v. Scribner, 109 Mass. 487, 488 (1872) ; Attorney General v. Briant, 15 M. \& W. 169, 170, 153 Eng. Rep. 808, 809 (1846). See Note, 17 Texas L. Rev. 522 (1939).

22. See notes $29,39,42$ infra.

23. See State v. Archer, 32 N.M. 319, 334, 255 Pac. 396, 402 (1927).

24. See pp. 216-20 infra. 
The so-called informer's privilege-assertable by either the government or the court ${ }^{25}$ - has been the informer's traditional courtroom shield." ${ }^{20}$ This doctrine was originated by the common law to serve the public's interest in facilitating reports of crime: it permits the government to conceal the source of its communications. ${ }^{27}$ And under this rule a witness cannot be required to reveal whether he was the government's informant. ${ }^{28}$

But the government-either state or federal-has not been satisfied with suppression of identity alone; courts have been persuaded to veil in secrecy the contents of informers' reports by distorting the informer's privilege, as well as the state secrets, attorney-client, and official communications privileges.

Some courts have extended the informer's privilege and the state secrets privilege beyond their original scope by utilizing them to suppress the contents of informers' communications. ${ }^{29}$ Expanding the informer's privilege may occasionally be justifiable where publication of the informer's report would reveal his identity. ${ }^{30}$ But this practice is pursued even where the identity of

25. E.g., Worthington v. Scribner, 109 Mass. 487 (1\$72) (privilege ascertable by the government) ; Home v. Bentinck, 2 Brod. \& B. 130, 162, 129 Eng. Kep. 967, 920 (1820) ("[I]f the parties were willing to disclose the sources of their infurmation, they vould nut be suffered to do so by the judges.").

Obviously, the privilege would be valueless were the informer required to assert it, for in doing so he would reveal his identity. It would therefore appear that "informer's privilege" is a misnomer.

26. The informer's privilege originated in the courts of England. It was first used to permit the government to conceal names of those who informed of revenue frauds. Re: v. Akers, 6 Esp. 127, 170 Eng. Rep. 850 (1790).

With the extension of the informer's privilege to treason trials, Trial of Thomas Hardy, 24 How. St. Tr. 199 (1794) ; Rex v. Watson, 2 Stark 115, 171 Eng. Rep. 591 (1817), the scope of inquiry was further limited. The privilege was there applied to protect the channels through which communications were conveyed to the government. Thus a witness was not permitted to disclose either the identity of the person on whose advice he informed or the name of the government officer to whom he gave his information. Trial of Thomas Hardy, supra. This extension of the privilege was undoubtedly designed to protect the counter-espionage activities of the government.

Finally, the policy of protecting the identity of informers was recognized in civil suits. Home v. Bentinck, 2 Brod. \& B. 130, 129 Eng. Rep. 907 (1820), was an action for libel based on the report of a military inquiry. Since the report contained names of those who had informed to the inquiry, it was not admitted in evidence.

27. E.g., Mitrovich v. United States, 15 F.2d 163 (9th Cir. 1926); United States v. Mloses, 27 Fed. Cas. 5, No. 15, $\$ 25$ (E.D. Pa. 1827) ; State v. Fortin, 106 Me 382, 76 Atl. 896 (1910) ; State v. Martin, 55 S.D. 594, 227 N.W. 66 (1929).

28. Attorney General v. Briant, 15 M. \& W. 169, 153 Eng. Rep. 808 (1846).

29. Informer's Privilege: E.g., Gabriel v. MIcMIullin, 127 Iowa 436, 103 N.W. 355 (1905) ; Michael v. MIatson, 81 Kan. 360, 105 Pac. 537 (1909); People v. Laird, 102 Mich. 135, 60 N.W. 457 (1894).

State Secrets Prizilege: E.g., Worthington v. Scribner, 109 MIass. 487 (1872). Cf. King v. United States, 112 Fed. $98 S$ (5th Cir. 1902); State v. Erown, 2 Marrel (Del.) 380, 36 At1. 458 (1896) ; Krumin v. Brulsnes, 255 Ill. App. 503 (1930).

30. See People v. Laird, 102 MIich. 135, 60 N.W. 457 (1S94). 
the informant is already known. ${ }^{31}$ And frequently an informer's report is classified as a state secret. ${ }^{32}$ Traditionally, the state secrets privilege, ${ }^{33}$ applicable during peace as well as war, ${ }^{34}$ was limited to protecting military secrets, ${ }^{35}$ information essential to national security, ${ }^{36}$ and intelligence bearing on the nation's international relations. ${ }^{37}$ But courts have often classified informers' reports of ordinary law violations among the secrets of state..$^{38}$

In eleven states, statutes protecting "official communications" afford an additional basis for judicial shielding of informers' communications. ${ }^{30}$ Such laws provide that the contents of reports made to public officials in "official confidence" are privileged from revelation where the "public interest would suffer by disclosure." 40 While the scope of these enactments has never been precisely defined, they were designed to encourage communications concerning both law violations and other matters of special interest to state governments. ${ }^{41}$

Finally, upon facts deemed appropriate some courts justify withholding an

31. Michael v. Matson, 81 Kan. 360, 105 Pac. 537 (1909). Cf. Dellastatious v. Boyce, 152 Va. 368, 147 S.E. 267 (1929). Contra: Nola Electric v. Reilly, 11 F.R.D. 103 (S.D. N.Y. 1950). But the informer's privilege is not applicable where both the identity of the informer and the contents of his communication are known. Pihl v. Morris, 319 Mass. 577, 66 N.E.2d 804 (1946).

32. See note 29 sipra.

33. See, generally, 8 Wigmore, Evidence $\$ 2378$ (3d ed. 1940) ; A.L.I. Model Code of Evidence, Rule 227; Street, State Secrets-A Comparative Study, 14 Mod. L. Rev. 121 (1951).

34. See Pollen v. Ford Instr. Co., 26 F. Supp. 583 (E.D.N.Y. 1939).

35. See Bank Line, Ltd. v. United States, 163 F.2d 133 (2d Cir. 1947) (report of Naval Board of Inquiry) ; Firth Sterling Steel Co. v. Bethlehem Steel Co., 199 Fed. 353 (E.D. Pa. 1912) (drawings of armor-piercing projectiles); In re Grove, 180 Fed. 62 (3d Cir. 1910) (plans of submarine turbine propelling machinery).

36. See Totten v. United States, 92 U.S. 105 (1875) (contract for secret war services) ; United States v. Haugen, 58 F. Supp. 436 (E.D. Wash. 1944) (contract relating to secret War Department project) ; Duncan v. Cammell, Laird \& Co., [1942] A.C. 624 (report of submarine sinking). Cf. Cresmer v. United States, 9 F.R.D. 203 (E.D.N.Y. 1949).

37. See Duncan v. Cammell, Laird \& Co., [1942] A.C. 624, 642; O'Neill v. United States, 79 F. Supp. 827, 829 (E.D. Pa. 1948).

38. See note 29 supra.

39. Cal. Code Crv. Proc. \$1881(5) (Deering; 1953); Idaho Code AnN. \$9-203 (1948); Iowa Code Ann. $\$ 622.11$ (1950); Minn. Stat. Ann. $\$ 595.02(5)$ (1947); Mont. Rev. Code Ann. §93-701-4(5) (1949); Neb. Rev. Stat. § 25-1208 (1948); Nev. Comp. Laws Ans. $\$ 8975$ (1930); N.D. Rev. Code $\$ 31-0106$ (1944); ORE. Comp. Laws Ann. § 3-104(5) (1940); S.D. Code \$36.0101(5) (1939); Wash. Rev. Stat. ANN. $\S 1214(5)$ (Remington, 1932). Georgia has a similar statute. GA. Cove ANN. $\$ 38-1102$ (1937).

40. For example, the Oregon statute states: "A public officer shall not be examined as to communications made to him in official confidence when the public interest would suffer by the disclosure." ORE. CONP. LAwS ANN. \$3-104(5) (1940).

41. See Sanford, supra note 18 , at 82. 
informer's communication by advancing the attorney-client privilege. ${ }^{22}$ This privilege forbids an attorney to disclose any communication made to him by a client in the course of consultation. ${ }^{43}$ It has been utilized to prevent a prosecuting attorney from revealing what was told to him by an informer.4 And while this rationale would not be available where the informant communicated with a police officer who was not an attorney, reports to Federal Bureau of Investigation agents, most of whom are lawyers, ${ }^{45}$ might be protected. ${ }^{20}$

\section{Assuring Fair Play to Parties}

Generally, withholding the identity of an informer poses no problems to a defendant. If the informer has merely provided a lead to competent evidence of a crime, knowledge of his identity would satisfy curiosity but ordinarily would not aid a party in the making of his case. ${ }^{47}$ But in some situations a defendant will need to know the name of an informer to meet the case against him. This may occur both where the informant supplied a "tip" and where his communication is introduced in evidence. And the law does not provide unlimited protection to the identity of informers. Where suppression of an

42. E.g., Vogel v. Gruaz, 110 U.S. 311 (18S4); Oliver v. Pate, 43 Ind. 132 (1873); Gabriel v. AIcMullin, 127 Iowa 426, 103 N.W. 355 (1905) ; Lewis v. Roux Truching Corp., 222 App. Div. 204, 226 N.Y. Supp. 70 (3d Dep't 1927) ; Ratzlaff v. State, 122 Ol:la. 203, 249 Pac. 934 (1926). Contra: Vernon v. State, 49 Ga. App. 1S7, 174 S.E 545 (1934); Granger v. Warrington, S Ill. 299 (1S46) ; Cole v. Andrews, 74 Minn. 93, 76 N.W. 962 (1898) ; Centoamore v. State, 105 Neb. 452, 181 N.W. 1S2 (1920) ; Cobb v. Simon, 119 Wisc. 597 (1903).

43. See 8 Wigarore, Evmence $\$ 2291$ (3d ed. 1940); Radin, The Privilege of Corfidential Commnnication Between Laugyer and Client, 16 CALrF. L. REv. 487 (1923).

44. E.g., Vogel v. Gruaz, 110 U.S. 311 (18S4); Lewis v. Roux Truclsing Corp., 222 App. Div. 204, 226 N.Y. Supp. 70 (3d Dep't 1927).

45. See Hoover, The Civil Inzestigation of the F.B.I., 1 Syrucuse L. Rew. 380, 3\&? (1950).

46. The Government has already argued that FBI reports should be grivileged from discovery as "work products" of lawyers. United States v. Cotton Valley Operators Comm., 9 F.R.D. 719 (W.D. La. 1949), aff'd by an cqually divided court, 339 U.S. 940 (1950). See the discussion of this case in Taine, Discoecry of Trial Profarations in the Federal Courts, 50 CoL. L. Rev. 1026, 1044 n.10S (1950). See also O'Neill v. United States, 79 F. Supp. 827 (E.D. Pa. 194S). Cf. Altmont v. United States, 177 F.21 971 (3d Cir. 1949), cert. denied, 339 U.S. 967 (1950). While the courts have usually rejeeted this argument, they have included communications to other government attorneys carrying on investigations within the "work product" dectrine. United States v. Deere, 9 F.R.D. 523 (D. Minn. 1949). An argument could be made that communications between FBI agents and informers fall within the attorney-client privilege.

47. "[T]he information ... obtained by the police furnished only the impulse for the act-the watch and search. The information itself was not used as evidence of guilt, and the fact of guilt itself is really not denied. .. . To have required, under these circumstanees, that the name of the informant should be disclosed, would merely have gratified his curiosity or his vengeance, whichever was most involved, without affecting in any way the pending question before the court." Shore v. United States, 49 F.2d 519, 523 (D.C. Cir. 1931). Cf. United States v. Keown, 19 F. Supp. 639, 646 (W.D. Ky. 1937). 
informer's identity would prevent a party to an action from making out his case, courts have deferred to federal and state constitutional safeguards.

Most frequently it is where the government undertakes a criminal prosecution that revelation of an informer's identity is desired. And the accused has at his command the Sixth Amendment and analogous state provisions, ${ }^{48}$ guaranteeing to him the "right ... to be confronted with the witnesses against him." 49 The requirement of confrontation is a codification of the common law hearsay rule, which prohibits introduction of an unproduced witness' testimony ${ }^{50}$ and reserves to the accused a right of cross-examination. ${ }^{51}$ This constitutional command protects an accused where the contents of an in-

48. "In all criminal prosecutions, the accused shall enjoy the right . . . to be informed of the nature and cause of the accusation; to be confronted with the witnesses against him. ..." United States Const. Amend. VI. For a general discussion of the history and scope of the Sixth Amendment, see Heller, The Sixth Amendaent to the ConstituTION OF THE UNITED STATES (1951).

49. While it has been held that the Sixth Amendment is not applicable to state court proceedings, West v. Louisiana, 194 U.S. 258 (1904), forty-six states have constitutional or statutory provisions requiring that the accused shall be "confronted with the witnesses against him" or "brought face to face" with them. 5 Wigmore, Evidence $\$ 1397$ (3d ed. 1940). And the Supreme Court has suggested that the right of confrontation may be a part of the Fourteenth Amendment. "A person's right to reasonable notice of a charge against him, and an opportunity to be heard in his defense-a right to his day in courtare basic in our system of jurisprudence; and these rights include, as a minimum, a right to examine the witnesses against him...." In re Oliver, 333 U.S. 257, 273 (1948).

The Sixth Amendment is applicable only to a "criminal prosecution." United States v. Zucker, 161 U.S. 475 (1896). Thus it has been held that the Sixth Amendment does not apply to extradition proceedings, Ex parte La Mantia, 206 Fed. 330 (S.D.N.Y. 1913), to a preliminary hearing, Burall v. Johnston, 53 F. Supp. 126 (N.D. Calif. 1943), to grand jury proceedings, Gilmore v. United States, 129 F.2d 199 (10th Cir.), cert. devicd, 317 U.S. 631 (1942), or to habeas corpus proceedings, Burgess v. King, 130 F.2d 761 (8th Cir. 1942). For a further discussion of the scope of the Sixth Amendment, see Note, 60 Y YLE L.J. 736, 738 (1951).

50. "The origin of this requirement of confrontation grew out of and is part of the hearsay rule, which is defined as the rule which prohibits the use of a person's assertion as equivalent to testimony to the fact asserted, unless the asserter is brought to testify in court on the stand, where he may be probed and cross-examined as to the grounds of his assertion and his qualifications to make it." Williams v. State, 42 Okla. Crim. 399, 403, 276 Pac. 515, 516 (1929). See also Salinger v. United States, 272 U.S. 542, 548 (1926); HELLER, op. cit. supra note 48, at 104.

The hearsay rule's exceptions are also part of the Sixth Amendment. Dowdell v. United States, 221 U.S. 325 (1911); Note, 28 N.C.L. Rev. 205, 207 (1950). Sce also 5 Wigmore, Evidence $\$ 1397$ (3d ed. 1940).

For a detailed discussion of the hearsay rule, see 5 Wigmore, Evidence (3d ed. 1940); Morgan, The Hearsay Rule, 12 WAst. L. Rev. 1 (1937).

51. "The constitutional right of confrontation is preliminary to and but another name for the right of cross-examination." State v. Crooker, 123 Me. 310, 313, 122 Atl. 865, 866 (1923). See Mattox v. United States, 156 U.S. 237, 242 (1895) (stressing also the value of demeanor evidence). See also State v. Perry, 210 N.C. 796, 188 S.E. 639 (1936); Rotrschaefer, Constitutionai Law 796 (1939); Note, 28 N.C.L. Rev. 205, 207 (1950). 
former's communication are openly introduced in evidence but his identity is withheld. ${ }^{52}$

An accused may also derive protection from the Fifth and Fourteenth Amendments' due process requirements. ${ }^{53}$ Even where the informer's communication is not considered by the court and is not introduced in evidence, disclosure of the informer's identity may be commanded. Courts will compel revelation of informers' identity where such disclosure is necessary or likely to show the innocence of the defendant ${ }^{54}$ or is in some other way essential to the defense, ${ }^{55}$ or where it will lessen the risk of false testimony. disclosure is also demanded where the informer is not a "mere informer," but instead a person who took part in the conduct relied upon by the government to prove its case. ${ }^{.57}$

52. "This provision of the statute [a provision of the Philippine Bill of Rights similar to the Sixth Amendment] intends to secure the accused in the right to be tried, so far as facts provable by witnesses are concerned, by only such witnesses as meet him face to face at the trial, who give their testimony in his presence, and give to the accused an ogportunity of cross-examination. It was intended to prevent the conviction of the accuscd upon depositions or ex parte affidavits, and particularly to preserve the right of the accused to test the recollection of the witness. . ." Dowdell v. United States, 221 U.S. 325, 330 (1911). See also Williams v. State, $19 \mathrm{Ga} .402,403$ (1856); HeLLE, op. cit. supra note 48 , at 105.

However, where an informer's communication is used simply as a lead to a hw violation, concealing his identity does not violate the Sixth Amendment. Dear Ched: Quong v. United States, 160 F.2d 251 (D.C. Cir. 1947). Cf. Curtis v. Rives, 123 F.2d 936 (D.C. Cir. 1941). In such a case, nothing the informer has said or done constitutes part of the evidence relied on by the government in its case. The informer served only as a stimulus; so stimulated, the law enforcement agency proceeds to erect its case.

53. Parsons v. State, 251 Ala. 467, 3S So.2d 209 (1948).

The Fifth Amendment provides: "No person shall . . . in any criminal case . . . be deprived of life, liberty, or property, without due process of law. . . ." Umrad STates Const. AzIEnd. $V$.

The Fourteenth Amendment provides: ". . . nor shall any State deprive any person of life, liberty, or property, without due process of law. ..." Uiriteo Stares Co:isr. Avieno. XIV.

While the Fifth Amendment places restrictions on the powers of the national Government, Barron v. Baltimore, 7 Pet. 242 (U.S. 1833), the Fourteenth Amendment prohibits certain kinds of action by a state, Civil Rights Cases, 109 U.S. 3 (1883).

54. See United States v. Li Fat Tong, 152 F.2d 650, 652 (2d Cir. 1945); Smith v. United States, 9 F.2d 386, 387 (9th Cir. 1925) ; Parsons v. State, 251 Ala. 467, 473, 38 So.2d 209, 213 (1948). See also Regina v. Richardson, 3 F. \&. F. 693, 694, 176 Eng. Rep. 318,319 (1863) ; Marks v. Beyfus, 25 Q.B.D. 494,498 (1890) ("[I]f upon the trial of a prisoner the judge should be of the opinion that the disclosure of the name of the iniormant is necessary or right in order to shew the prisoner's innocence, then ene public policy is in conflict with another public policy, and that which says that an innocent man is not to be condemned when his innocence can be proved is the policy that must prevail.").

55. See Scher v. United States, 305 U.S. 251, 254 (193S) ; Sorrentino v. United States, 163 F.2d 627, 629 (9th Cir. 1947).

56. Wilson v. United States, 59 F.2d 390 (3d Cir. 1932).

57. United States v. Conforti, 200 F.2d 365 (7th Cir. 1952). Cf. United States v. Schneiderman, 104 F. Supp. 405 (S.D. Calif. 1952). 
Finally, court rules motivated by constitutional provisions proscribing unreasonable searches, seizures, and arrests may preserve an accused's right to fair trial. ${ }^{58}$ Where a search and seizure or arrest-with or without warrantwas based solely on an informer's statement, the prosecution must reveal the identity of the informant upon whose credibility depends existence of the probable cause requisite to lawful police action. ${ }^{50}$ Only by knowing the informant's identity can the accused attack his reliability, thus permitting the

58. The Fourth Amendment provides: "The right of the people to be secure in their persons, houses, papers, and effects, against unreasonable searches and seizures, shall not be violated, and no warrants shall issue, but upon probable cause, stupported by oath or affirmation. . .." United States Const. Amend. IV. The constitution of every statc contains a clause like that of the Fourth Amendment, and often in its precise words. For a collection of the state provisions, see Justice Frankfurter's opinion in Harris v. United States, 331 U.S. 145, 160 (1947).

The Fourth Amendment "does not forbid all searches and seizures, but only those that are unlawful because not based upon probable cause or upon a warrant where a warrant is required." Cannon v. United States, 158 F.2d 952, 954 (5th Cir.), cert. denied, 330 U.S. 839 (1947). To enforce the Fourth Amendment's provisions, federal courts have adopted an "exclusionary rule"; evidence illegally obtained is excluded from the prosecution's case. Weeks v. United States, 232 U.S. 383 (1914) ; Boyd v. United States, 116 U.S. 616 (1886). Nineteen states have adopted a similar rule. See Comment, 58 Yale L.J. 144, 150 n.31 (1948). See also Atkinson, Adnrissibility of Evidence Obtained Throngh Unrcasonable Searches and Seizures, 25 CoL L. Rev. 11 (1925); Harno, Evidence Obtained by Illcgal Search and Seizure, 19 Ill. L. Rev. 303 (1925) ; Edwards, Standing to Suppress Utrecasonably Seized Evidence, 47 Nw. U.L. REv. 471 (1952).

59. Search and Seizure Without a Warrant: Wilson v. United States, 59 F.2d 390 (3d Cir. 1932) ; United States v. Keown, 19 F. Supp. 639 (W.D. Ky. 1937); Hamilton v. State, 149 Miss. 251, 115 So. 427 (1928). Contra: Goetz v. United States, 39 F.2d 903 (5th Cir. 1930).

Search and Seizure With a Warrant: United States v. Reynolds, 111 F. Supp. 589 (D.D.C. 1953).

Arrest Without a Warrant: Smith v. State, 169 Tenn. 633, 90 S.W.2d 523 (1936). Cf. McQuaid v. United States, 198 F.2d 987 (D.C. Cir. 1952) ; United States v. Heitner, 149 F.2d 105 (2d Cir. 1945).

Some cases have refused disclosure where there was sufficient evidence of probable cause without revelation of the informer's identity. Scher v. United States, 305 U.S. 251 (1938); United States v. Bianco, 189 F.2d 716 (3d Cir. 1951) ; Harris v. State, - Miss، -, 63 So.2d 396 (1953).

While disclosure of an informer's identity may be necessary in order to test probable cause as required by the Fourth Amendment, the defendant's right to demand such disclosure is based on due process. This is another situation where "if what is asked is usem ful evidence to vindicate the innocence of the accused or lessen the risk of false testimony or is essential to the proper disposition of the case, disclosure will be compelled." Wilson v. United States, 59 F.2d 390, 392 (3d Cir. 1932), 46 HARv. L. Rev. 343. Thus where the defendant does not allege that knowledge of the informer's identity is essential to his defense or that he believes that the police officer is testifying falsely, disclosure may not be required. Medina v. United States, 158 F.2d 955 (5th Cir. 1946) ; McInes v. United States, 62 F.2d 180 (9th Cir. 1932); Shore v. United States, 49 F.2d 519 (D.C. Cir. 1931). Cf. Husty v. United States, 282 U.S. 694 (1931). 
court to determine the probable cause issue. ${ }^{\infty}$ If it appears that the search and seizure or arrest was conducted without probable cause, evidence so obtained will be inadmissible in court ${ }^{61}$ and the arrest will be unlawful. ${ }^{22}$

Defendants may also desire to learn the identity of informers in the course of civil prosecutions undertaken by the government. ${ }^{63}$ Although the Government has been permitted to withhold the names of complainants in antitrust and wage-hour cases, ${ }^{64}$ the defendant's right to fair trial is generally safeguarded. Frequently the defendant is able to secure disclosure of the informant's identity on the theory that by bringing suit the Government has waived its right to suppress relevant material. ${ }^{05}$ But even if the waiver doctrine were not applied, the defendant would probably be protected from the introduction of testimony of an unknown witness. ${ }^{60}$

Moreover, constitutional weapons are available to combat the government's attempt, under whatever rationale, to withhold the contents of an informer's communication. In criminal cases, the accused again receives his greatest protection from the Sixth Amendment. ${ }^{67}$ This Amendment's command that "in all criminal prosecutions the accused shall enjoy the right . . . to be informed of the nature and cause of the accusation against him" guarantees the defendant an opportunity to rebut the charges against him. ${ }^{69}$ Accordingly, a court or jury cannot base its decision on an informer's communication un-

60. See, e.g., Scher v. United States, 305 U.S. 251 (193S); United States v. Heitner, 149 F.2d 105 (2d Cir. 1945); United States v. Blich, 45 F.2d 627 (D. Wyo. 1930), 22 J. Crar. L. \& Crininology 284 (1931) ; Smith v. State, 169 Tenn. 633, 90 S.W.2d 523 (1936).

61. Weeks v. United States, 232 U.S. 383 (1914); Boyd v. United States, 116 U.S. 616 (1886) ; United States v. Allen, 16 F.2d 320 (S.D. Fla. 1926).

62. E.g., United States v. Clark, 29 F. Supp. 139 (W.D. 110. 1939) ; People v. Chatman, 322 I11. App. 519, 54 N.E.2d 631 (1944). Cf. MIcQuaid v. United States, 193 F.2d 987 (D.C. Cir. 1952) ; United States v. Heitner, 149 F.2d 105 (2d Cir. 1945).

63. See, e.g., cases cited notes 64-6 infra.

64. Bowman Dairy v. United States, 341 U.S. 214 (1951) (antitrust); United States v. Shubert, 11 F.R.D. 528 (S.D.N.Y. 1951) (same); Walling v. Richmond Screw Anchor Co., 4 F.R.D. 265 (E.D.N.Y. 1943) (wage-hour).

65. Fleming v. Bernardi, 1 F.R.D. 624 (N.D. Ohio 1941). Cf. United States v. Keown, 19 F. Supp. 639, 646 (W.D. Ky. 1937). This doctrine might also be applied in criminal prosecutions.

66. The Sixth Amendment bars such a procedure in criminal cases, supra note 52. This amendment is simply a codification of the hearsay rule which applies to civil as well as criminal cases. Thus application of the hearsay rule in civil cases should produce a result similar to that found in criminal cases.

67. See notes $48-9$ supra.

68. "[T] the nature of the accusation against him, to the end that he may prepare his defence, and plead the judgment as a bar to any subsequent prosecution for the same ofiense." United States v. Simmons, 96 U.S. 360, 362 (1877). See HeLLER, op. cit. supra note 48, at 101. 
less its contents, as well as the informer's identity, are revealed to the defendant. ${ }^{69}$

Protection in both criminal and civil cases may come also from the Fifth and Fourteenth Amendments. Notions of due process place restrictions on the government's discretion to withhold the contents of an informer's report. It is the view of some courts that the government, by bringing an action, has waived any privilege to suppress the contents of an informant's communication if the information is "importantly relevant" to a party's defense. ${ }^{70}$

Tort Actions Against Informers. While a party is generally protected from unfair use of an informer's communication in the case which the informer helped to build, ${ }^{71}$ he does not fare so well where he seeks redress against one who informed falsely and maliciously. Often an informer's victim seeks redress through an action for libel, slander, or malicious prosecution. In such suits he will usually attempt to obtain disclosure of the informant's words, either through discovery procedures ${ }^{72}$ or by calling as a witness the informer or the government official to whom he communicated. ${ }^{73}$ Lacking such information, the plaintiff will ordinarily be unable to meet the respective requirements of the law of defamation and of malicious prosecution that the exact words complained of be produced, ${ }^{74}$ and that proof be made of the defendant's malice

69. Cf. United States v. Coplon, 185 F.2d 629 (2d Cir. 1950). Since the right of notice and confrontation are normally accorded, few cases involving undisclosed cvidence arise. See Frank, Cases on Constitutional Law 587 n.6 (rev. ed. 1952). However, the Supreme Court has alluded to the problem in a case involving state court proceedings. Dc Jong v. Oregon, 299 U.S. 353, 362 (1937). Cf. Rex v. Justices of Bodman, [1947] 1 K.B. 321.

70. United States v. Andolschek, 142 F.2d 503, 506 (2d Cir. 1944), where Judge Learned Hand put the Government to a choice: "either it must leave the transactions in the obscurity from which a trial will draw them, or it must expose them fully." See also United States v. Beekman, 155 F.2d 580 (2d Cir. 1946); United States v. Krulewitch, 145 F.2d 76 (2d Cir. 1944) ; Attorney General v. Tufts, 239 Mass. 458, 132 N.E. 322 (1921). Contra: Arnstein v. United States, 296 Fed. 946 (D.C. Cir. 1924). See United States v. Watkins, 67 F. Supp. 556, 561 (S.D.N.Y. 1946). Cf. United States v. DeNormand, 149 F.2d 622 (2d Cir. 1945) ; United States v. Ebeling, 146 F.2d 254 (2d Cir. 1944). However, there is no waiver in a civil forum where the Government is the defendant. United States v. Reynolds, 345 U.S. 1 (1.953).

Some courts, in requiring disclosure of the contents of an informer's communication, base their decision on reasons similar to those advanced when disclosure of the identity of an informer is required. See Centoamore v. State, 105 Neb. 452, 181 N.W. 182 (1920) (requiring disclosure of statements relating to the defendant's innocence); United States v. Schneiderman, 106 F. Supp. 731 (S.D. Calif. 1952) (requiring disclosure of documents essential to the defense).

71. See pp. 211-16 supra.

72. E.g., Schultz v. Strauss, 127 Wisc. 325,106 N.W. 1066 (1906).

73. E.g., Vogel v. Gruaz, 110 U.S. 311 (1884) (defamation); Worthington v. Scribner, 109 Mass. 487 (1872) (malicious prosecution).

74. Foltz v. Moore McCormack Lines, 189 F.2d 537, 539 (2d Cir.), cert. denicd, 342 U.S. 871 (1951) ("[I]n actions for libel or slander the false and defamatory matter should be pleaded in haec verba. ..."). Knowledge of the exact words may be necessary to prove malice. Bunton v. Worley, $7 \mathrm{Ky} .38$ (1815). 
and lack of probable cause in motivating prosecution. ${ }^{75}$ And both the informer and, occasionally, the government vigorously oppose disclosure. ${ }^{70}$ The courts have been perversely receptive to their pleas, accepting their assertions of distorted evidentiary privileges. ${ }^{77}$

Where courts have denied plaintiffs' requests for disclosure, they have broadened the area in which protection from defamation suits has traditionally been afforded. Communications to executive governmental officials concerning the qualifications of subordinates are not privileged from revelation by the substantive law of defamation $;^{78}$ they are conditionally privileged from being successfully used as the basis of a libel or slander action.90 And the usual rule is that reports of crime to law enforcement agents are also privileged conditionally, rather than absolutely. ${ }^{80}$ This qualified privilege evaporates in the face of evidence that the defendant-informer's report was false and motivated by malice. ${ }^{81}$ But when judges accept the assertion of warped evidentiary privileges to suppress the contents of an informer's report, the communication is in effect afforded the absolute privilege denied by substantive law. Without producing the defendant's words, the plaintiff has scant hope of carrying his day in court. ${ }^{s 2}$

75. E.g., Stewart v. Sonneborn, 98 U.S. 187 (1878); Levy v. Brannan, 39 Cal. 485 (1870).

76. E.g., State v. Tune, 199 Mo. App. 404, 203 S.W. 465 (1918) (objection by government) ; Marks v. Beyfus, 25 Q.B.D. 494 (1S90) (abjection by government); Steen v. First National Bank, 298 Fed. 36 (Sth Cir. 1924) (objection by informer) ; State v. Wilcox, 90 Kan. 80,132 Pac. 982 (1913) (objection by informer).

77. See notes $\& 8,92,99$ infra and accompanying text.

78. E.g., Blake v. Pilford, 1 M. \& R. 198, 174 Eng. Rep. 67 (1832). Cf. Schultz v. Strauss, 127 Wisc. 325, 329, 106 N.W. 1056, 1067 (1906).

79. E.g., White v. Nicholls, 3 How. 266 (U.S. 1845); Peinhardt v. West, $217 \mathrm{Ala}$. 12, 115 So. SS (1927). See Prosser, Torts $\$ 39$ (1941). Cf. Nate, 97 U. of. PA. L. Rex. 877 (1949).

80. E.g., Miller v. Nuckolls, 77 Ark. 64, 91 S.W. 759 (1905); Flanagan v. MIcLane, 87 Conn. 220, 87 Atl. 727 (1913) ; Eisenberg v. Reasenberg, 133 Mifs. 190, 231 N.Y. Supp. 49 (Sup. Ct. 1928). Contra: Wells v. Toogood, 165 Mfich. 677, 131 N.W. 124 (1911); Johnson v. Evans, 3 Esp. 32, 170 Eng. Rep. 523 (1799). See Comments, 30 Texis L. Rev. 875, $\$ 82$ (1952), and 51 CoL. L. REv. 244, 246 (1951); 27 N.Y.U.L. REv. 170, 171 (1952); 65 HaRv. L. REv. 35\&, 359 (1951).

However, where the law requires that a report be submitted, an absolute privilege is imposed on otherwise libelous matters. Stainey v. Standard Oil Co., 71 N.D. 170, 299 N.W. 582 (1941) (mandatory report to State Workmen's Compensation Bureau).

81. E.g., Briggs v. Byrd, 34 N.C. 377 (1851) ; Hathaway v. Brugginl, 168 Wisc 390 , 170 N.W. 244 (1919) ; Dickson v. Earl of Willon, 1 F. \& F. 419, 175 Eng. Rep. 790 (1859). Cf. Note, 25 MLARQ. L. REv. 156 (1941).

82. See notes 74-5 supra. See also S WigMone, Evidence $\$ 2374$ (3d ed. 1940): "To deny production [in an action against the informant for libel] is in effect to declare that the libel is privileged from liability. If that is indeed the judicial belief and the law, it should be frankly declared; if not, the action should not be defeated by an evasion which pretends to keep secret that which is not secret." See also Comment, 22 CuLrF. L. REv. 657, 670 n.15 (1934). 
And the subject of an informer's spite is offered an empty alternative by the law of malicious prosecution. In theory, this remedy is available to one who has received a favorable verdict in a criminal or civil action inspired by an informer who acted maliciously and without probable cause. ${ }^{83}$ But a plaintiff is hard put to prove the last two elements of his cause where testimonial privileges prevent him from introducing the informer's words in evidence. ${ }^{84}$

However, expanded protection of informers from defamation and malicious prosecution actions is unwarranted in both law and policy. The stibstantive law provides absolute immunity to the honest informant. ${ }^{85}$ Thus utilization of testimonial privileges in this context serves no higher function than the absolute protection of the false and malicious informer. ${ }^{80}$ But the government can have no valid interest in hearing untrue charges spitefully made. ${ }^{87}$ And the courts commit error and create confusion when they supplement the substantive law by bending respectable evidentiary privileges to their purposes.

Some courts have extended the informer's privilege and the state secrets privilege beyond their original scope to suppress the contents of an informant's communication, even though his identity has already been revealed. ${ }^{88}$ But the policy underlying the state secrets privilege generally is not applicable to informers' reports. ${ }^{89}$ Although this privilege may properly be asserted where revelation of informers' communications would threaten national security or international relations, reports relating to ordinary law infractions do

83. E.g., Larocque v. Dorsey, 299 Fed. 556 (2d Cir. 1924) ; Glenn v. Lawrence, 280 III. 581,117 N.E. 757 (1917).

84. See Bazzell v. Illinois Central R.R., 203 Ky. 626, 262 S.W. 966 (1.924).

85. See note 81 supra. The statements of various courts indicate that the stibstantive law is not aimed at honest informants. Miller v. Nuckolls, 77 Ark. 64, 73, 91 S.W. 759, 762 (1905) (defamation-"It is doubtful if he was under any duty to voluntarily repeat mere rumors of that kind affecting the character of an unmarried woman, even to an officer of the law; and if he did so maliciously, an action would lie.") ; Kintz v. Harriger, 99 Ohio 240, 249, 124 N.E. 168, 171 (1919) (malicious prosecution-"I can conceive of no good reason why the grand jury should be 'free and unobstructed' to the lawless, the conscienceless, and the utterly irresponsible citizen who seeks to work reprisals upon his fellows.").

86. "The [testimonial] privilege thus has the effect of granting to the defendant an immunity from responsibility regardless of the wanton nature of his act. It is conceivable that in some cases gross injustices might occur." Comment, 22 CALIF. L. REv. 667, 670 n.15 (1934).

87. "Where information is obtainable on which to base suits against informers having but a qualified privilege, there is, of course, some deterrent to their willingness to act without reserve in the danger that some jury might find malice, contrary to the fact. . . . On the other hand, it may be even more desirable to allow some restraint in order to reduce the waste of requiring the F.B.I. to investigate and deal as best it can with false charges maliciously made." Foltz v. Moore McCormack Lines, 189 F.2d 537, 540 (2d Cir. 1951), 27 N.Y.U.L. REv. 170 (1952).

88. See notes 29,31 supra.

89. See notes $33,35-7$ supra. 
not belong among the secrets of state. ${ }^{90}$ And an extension of the informer's privilege which can serve only to shield the dishonest and the malicious from tort actions is unwarranted. ${ }^{91}$

The government occasionally invokes legislation protecting "official communications" as a ground for judicial immunization of informers. ${ }^{22} \mathrm{~A}$ few state legislatures, apparently attempting to codify the hazy common law state secrets and informer's privileges, ${ }^{93}$ have provided that reports to public officials shall, in the public interest, be privileged from revelation. ${ }^{\text {ot }}$ The draftsmen, probably inadvertently, used broad language. ${ }^{95}$ Nevertheless, when the statutory rule is employed as a state secrets privilege, considerations warranting its application should be no less weighty than those motivating the original common law privilege. ${ }^{96}$ Thus in some instances these laws may justifiably provide blanket protection to informers. But where they are too facilely administered, tort plaintiffs are deprived of essential information without compensating gains accruing to the state. ${ }^{97}$ The public interest which might or might not "suffer by disclosure" should be carefully evaluated in each case, that courts may avoid the unfair consequences likely to result from exclusionary rules capriciously applied. ${ }^{98}$ And where the statutory rule is utilized as a codification of the extended informer's privilege to embrace contents, its application should be restricted to data not crucial to decision in defamation and malicious prosecution suits.

Frequently judges have occasion to withhold informers' communications upon assertion of the attorney-client privilege. ${ }^{.9}$ Consequently, a prosecuting attorney or an FBI agent may be prevented from revealing what was told him by an informer. ${ }^{100}$ The attorney-client privilege, by encouraging full disclosure, ${ }^{101}$ is designed to enable lawyers to represent their clients effectively. ${ }^{102}$

90. E.g., Worthington v. Scribner, 109 Mass. 487 (1872) (report of a customs law violation). See Haydock, Some Evidentiary Problems Poscd by Atomic Encrgy Sccurily Requirements, 61 HARv. L. Rev. 468 (1948).

91. See, e.g., Krumin v. Bruknes, 255 Ill. App. 503 (1930) (malicious communiation of plaintiff's brother-in-law classified as state secret).

92. E.g., People v. King, 122 Cal. App. 50, 10 P.2d S9 (1932) ; State v. MIcClendon, 172 Ifinn. 106, 214 N.W. 782 (1927); State v. Hoben, 36 Utah 186, 102 Pac. 1000 (1909).

93. See State v. Hoben, supra note 92.

94. See note 40 supra.

95. See 8 WigMore, Evidence 786 (3d ed. 1940).

96. For situations in which the state secrets privilege may be involked, see cases cited in notes 35-7 supra.

97. Cf. People v. King, 122 Cal. App. 50, 10 P.2d $\$ 9$ (1932); State v. 1 fcClendon, 172 Minn. 106, 215 N.W. 782 (1927) ; State v. Ayer, 122 Ore. 537, 259 Pac. 427 (1927).

98. See Cole v. Andrews, 74 Minn. 93, 76 N.W. 962 (1S9S), where the court properly refused to apply the privilege. See also $1 \mathrm{BL}$ Comas. 139 . Cf. Lindsey v. People, 65 Colo. 343, 181 Pac. 531 (1919).

99. See note 42 supra.

100. See respectively notes 44,46 sipra.

101. See note 43 supra.

102. "The necessary but fictitious assumption which charges everyone, in the conduct of his own actions and affairs, with a knowledge of the law even more complete than in 
But the government official to whom an informer communicates is a representative of the public; unlike the private attorney, he is not intended to become the active protagonist of an individual's cause. ${ }^{103} \mathrm{His}$ advice and effort must be attuned to the public welfare and cannot be directed solely to protection of an informer's interests. ${ }^{104}$ The attorney-client privilege, as well as other testimonial privileges, should not be dressed to double as an absolute privilege from liability for defamation and malicious prosecution.

In the courtroom the public interest in facilitating use of informers is judicially balanced against the demands of fair play for parties, except in the area of tort redress. But all "trials" are not conducted in courts and all "rights" are not adjusted by judges and juries; extra-judicial proceedings-the socalled administrative process-play an increasingly important rôle in American life. ${ }^{105}$ These procedures have been specifically designed to avoid courtroom formality. ${ }^{100}$ But in the streamlining process, fairness to the subjects of ad-

fact possessed by her ablest ministers, renders it equally necessary to an adequate administration of justice that her officers appointed and accredited for that purpose, shall be available for confidential consultation in order that they may supply, to the extent of their learning and ability, the actual deficiency in a suitor's presumed knowledge of the law, as if they were that suitor's other self. They would not be thus 'available' if the confidences reposed in them might be betrayed either by them or by the agents of either confidentially employed to communicate such confidences." State v. Loponio, 88 Atl. 1045, 1047 (N.J. Ct. Err. \& App. 1913).

103. E.g., Cole v. Andrews, 74 Minn. 93, 76 N.W. 962 (1898); Centoamore v. State, 105 Neb. 452, 181 N.W. 182 (1920) ; Needham v. State, 90 Tex. Crim. 86, 233 S.W. 966 (1921). See also Granger v. Warrington, 8 I1l. 299, 309 (1846) : "Granger can be considered in no other light than a witness on the part of the people, communicating to the law officer of the Government, his knowledge in relation to the commission of a supposed crime, and inquiring of that officer whether the facts thus communicated amounted to an offence. We think that no considerations of public policy require that the conversation between Granger and the State's Attorney should be regarded as confidential and privileged. It would be an unnecessary extension of the rule in relation to confidential communications and ought not, therefore, to be allowed."

104. "[The government official] was . . a a sworn minister of justice, whose duty it was, while endeavoring to bring the guilty to punishment, to take care that the innocent should be protected. . . . Communications made to him for the purpose of involing official action are supposed to be made for the purposes of public justice, and the party making them can assume no control as to the use that shall be made of them subsequently." Pcople v. Davis, 52 Mich. 569, 573, 18 N.W. 362,363 (1884).

105. For an excellent treatise on administrative law, see Davis, AdMinistrutive Law (1951). For additional material on the administrative process, its growth and significance, sce Dickinson, Administrative Justice and the Supremacy of Law (1927) ; Freund, Administrative Powers over Persons and Property (1928); Pound, Administindtive LAW (1942); Pusey, Big GovernMent (1945).

106. In his successful veto of the Walter-Logan bill in 1940, President Roosevelt compared the judicial and administrative processes: "Court procedure is adapted to the intensive investigation of individual controversies. But it is impossible to subject the daily 
ministrative action has often been slighted ${ }^{107}$-and never more markedly than in agencies' use of informers.

\section{The Inforamer in the Adainistrative Process}

In the administrative process, informers are utilized in a manner which would never be sanctioned in courtroom proceedings. ${ }^{108}$ Some decisions are based wholly on information withheld from the party ${ }^{109}$ and even where the contents of an informer's communication is openly introduced in evidence, the informer's identity is often concealed. ${ }^{110}$ In the federal government's employee security program, for example, "ironclad secrecy" surrounds the

routine of fact-finding in many of our agencies to court procedure. Litigation has bexome costly beyond the ability of the average person to bear. Its technical rules of procelure are often traps for the unwary and technical rules of evidence often prevent commin-sense determinations on information which would be regarded as adequate fur any business decision. The increasing cost of competent legal advice and the necessity of relying upen lawyers to conduct court proceedings have made all laymen and most lawyers recognize the inappropriateness of entrusting routine processes of government to the outcome of neverending lawsuits.

"The administrative tribunal or agency has been evolved in order to handle controversies arising under particular statutes. It is characteristic of these tribunals that simple and nontechnical hearings take the place of court trials, and informal proceedings supersede rigid and formal pleadings and processes. A common-sense resort to usual and practical sources of information takes the place of archaic and technical applieatiun of rules of evidence. ..." 86 Cong. REc. 13942 (1940).

107. See Justice Jackson's dissenting statement in SEC v. Chenery Corp., 332 U.S. 194, 217 (1947) : "I have long urged, and still believe, that the administrative prusess deserves fostering in our system as an expeditious and non-technical method of affying lowo in specialized fields. I can not agree that it be used, and I thinl: its continued effeetiveness is endangered when it is used, as a method of dispensing arith lan in those fields."

108. See Judge Edgerton's dissenting opinion in Bailey v. Richardson, 182 F.2d 46, 66 (D.C. Cir. 1950): "Without trial by jury, without evidence, and without even teing allowed to confront her accusers or to know their identity, a citizen of the United States has been found disloyal to the government of the United States." See also O'Brian, Loyalty Tests and Guilt by Association, 61 Harv. L. Rev. 592, 609 (1948).

One of the most blatant attempts to avoid courtroom procedures is seen in the Emergency Detention Act of 1950. The Act provides that upon the declaration of an "Internal Security Emergency" by the president, the Government may apprehend "each percon as to whom there is reasonable ground to believe that such person probably will engage in, or probably will conspire with others to engage in, acts of espionage or of sabotage" At the hearing of those detained, the "Attorney General or his representative shall not be required to furnish information the revelation of which would disclose the identity or evidence of Government agents or officers which he believes it would be dangerous to national safety and security to divulge" 64 STAT. 1019 (1950), 50 U.S.C. \$ \$14(d) (Supp. 1952).

There are also opportunities to utilize informers in non-government areas. See Comment, Loyalty and Prizate Entployment: The Right of Employers to Discharge Suspacted Subiersives, 62 YaLE L.J. 954 (1953).

109. See note 132 infra. Cf. Van Knorr v. Miles, 60 F. Supp. 962 (D. Mass. 1945).

110. E.g., Kwock Jan Fat v. White, 253 U.S. 454 (1919). 
names of informants ${ }^{111}$ - and some of the agencies probably render adverse determinations of "loyalty" on the basis of informers' evidence never disclosed to the parties. ${ }^{112}$

The reports of the Federal Bureau of Investigation, containing the communications of informers, furnish the principal source of confidential information in the administrative process. ${ }^{113}$ These reports are kept secret on the theory that disclosure would seriously endanger national security and eliminate the Bureau's effectiveness. ${ }^{114}$ But administrative agencies prescribe no standard size for the cloak of secrecy veiling FBI reports. In some cases the contents are revealed only to the deciding body ;15 in others, they are disclosed in varying degrees of specificity to the parties. ${ }^{110}$ But in most cases the identity of the informer and the person to whom he communicated remains unknown to both the deciding body and the parties before it. ${ }^{117}$ Generally a report states that information was received from " $\mathrm{T}-1$, a person of known reliability," and the recipient of the information is not named.118 Thus the contents of an informer's communication may form the basis of an administrative decision even though the deciding body is unaware of the identity of both the informant and his governmental "contact."110 By extending the role of informers, the administrative process has placed greater emphasis on speedy procedures than upon fair play.

111. See Bontecou, The Federal Loyalty-Security Program 61 (1953). On April 27, 1953, President Eisenhower abolished the Loyalty Program and substituted a Security Program, N.Y. Times, April 28, 1953, p. 20, col. 2. However, "under the new systemas under the old-[employees] might be dismissed on the basis of a case initiated after accusations from anonymous accusers." Id. col. 5. The new Security Program has been criticized by the American Civil Liberties Union as failing "to provide cross-examination ... a right which is basic to a fair hearing." A.C.L.U. WEEKLY BuLL. \#1601 (July 6, 1953).

112. Bontecou, op. cit. supra note 111, at 63. For a discussion of the use of confidential information in the Port Security Program, see Brown \& Fassett, Security Tcsts for Maritime Workers: Due Process under the Port Security Program, 62 Y ALE L.J. 1163, 1177-82 (1.953).

113. See Hoover, Civil Liberties and Law Enforcement: The Role of the F.B.I., 37 Iowa L. Rev. 175 (1952); Hoover, Civil Investigation of the F.B.L., 1 SyrAcuSE L. REv. 380 (1950) ; Hearings, supra note 15, at 328; 51 CoL. L. Rev. 244, 245 (1951).

114. Hearings, supra note 15 , at 328 . See also note 16 supra.

115. See Knauff v. Shaughnessy, 338 U.S. 537 (1950). See also KnuUfF, Tre ElLEN KNAUFF STORY (1952).

116. See Bontecou, op. cit. supra note 111.

117. See Richardson, The Federal Employee Loyalty Program, 51 CoL L. Rev. 546, 549 (1951). See also Bontecou, ap. cit. supra note 111. And in Brief for Appellant, p. 17, Bailey v. Richardson, 182 F.2d 46 (D.C. Cir. 1950) it is pointed out that the name of the person to whom the informer reported-the FBI agent-is unknown.

118. See Emerson and Helfeld, Loyalty Among Government Employecs, 58 YALE L.J. 1, 103 (1.948) ; O'Brian, New Encroachnents on Individual Freedom, 66 HaRv. L. Rev, 1, 19 (1952). Cf. Lasswell, National Security and Individual Freedom 209 n.9 (1950).

119. See notes 117,118 supra. 


\section{Facilitating the Use of Informers}

Where appellate courts have approved this deviation from the balance ordinarily maintained in courtroom proceedings, they have attempted to rationalize their decisions by drawing nice distinctions between "rule-making" and "adjudicatory" proceedings, between "rights" and "privileges," and by denominating administrative proceedings "non-criminal." The place of informers has been expanded in those administrative proceedings which courts label "legislative" or "rule-making" rather than "judicial," "quasi-judicial," or "adjudicatory." 120 The former supposedly look to the future and prescribe general rules of conduct for broadly identified situations, ${ }^{121}$ while the latter are immediately applicable to individuals in their individual capacities. ${ }^{122}$ When an administrative proceeding fits into the "legislative" or "rule-making" category, confidential reports may form the basis of the deciding body's determination. ${ }^{123}$ Courts also sanction an extended rôle for informers in administrative proceedings which involve "privileges" rather than "rights."124 A

120. Prior to the passage of the Administrative Procedure Act, CO STAT. 237 (1946), as amended, 5 U.S.C. $\$ \S 1001$ it seq. (Supp. 1952), courts distinguished between "Iegislative" and "judicial" or "quasi-judicial" proceedings. See, e.g., Prentis v. Atlantic Coast Line Co., 211 U.S. 210 (1908). The APA classifies administrative actions as "rule-mal:ing" and "adjudication." The relationship between these two sets of labels is clear. See Administrative Procedure Act-Legislative History, Sew. Doc No. 248, 79th Cong., $2 d$ Sess. (1946). In general, "we speak of rule or rule-making whenever agencies are exercising legislative powers. We speak of order and adjudication when they are doing things which courts otherwise do." Id. at 355. Sec also Willapoint Oysters, Inc. v. Eving, 174 F.2d 676, 692 (9th Cir. 1949) : "The Administrative Procedure Act is bascd upon a brosd and logical dichotomy between 'rule-making' and 'adjudication', i.e., legislative and judicial functions."

121. For a discussion of the various possible definitions of these terms, see Davs, of. cit. supra note 105, at 1St (1951). See also Fuchs, Procedure in Adninistratiz'c Rulc-Mal:ing, 52 HARv. L. REv. 259, 265 (1938); Green, Scparation of Goicnimental Potecrs, 29 YALE L.J. 369, 373 (1920).

122. See Dickinson, op. cit. supra note 105, at 21 ; Green, supra note 121.

123. Norwegian Nitrogen Products Co. v. United States, 28S U.S. 294 (1933).

In the pre-APA era, courts "imposed much less onerous procedural requirements in cases which concerned the exercise of functions which are legislative in nature." Schwartz, Adnimistrative Termintology and the Administratice Procedure Act, 4S MIIcr. L. REv. 57, 66 (1949). See Netterville, The Administratice Proccdure Act: A Sludy in Interpretation, 20 GEo. WASH. L. REv. 1, 11 (1951). Thus, actions could be taken without requiring an opportunity for a hearing. Chicago, B. \& Q.R.R. v. Nebraska, 170 U.S. 57 (1898). However, the APA prescribes situations in which parties affected by administrative rule-mal:ing must be given notice of and a chance to participate in the proceeding. A distinction is made between "formal" and "informal" rule-making, with the former usually requiring a hearing and the procedural protection prescribed by the Act. See Comment, 56 YALE L.J. $670,675-6$ (1947). But the benefits accorded by the APA are not grounded in the due process clause. They are accorded where "rules are required by stainte to be made on the record after opportunity for an agency hearing." Adsismistalitive Procroune Acr $\$ 4$ (b) (emphasis supplied).

124. E.g., Knauff v. Shaughnessy, 338 U.S. 537 (1949). 
government job, ${ }^{125}$ a passport, ${ }^{120}$ a license, ${ }^{127}$ a parole, ${ }^{128}$ use of the mails, ${ }^{120}$ and a conscientious objector Selective Service classification ${ }^{130}$ have all at times been deemed "privileges." As such, the manner of their granting or denial has been held free of constitutional restraint. ${ }^{131}$ Consequently, "privileges" have been denied solely on the basis of information never revealed to the party involved. ${ }^{132}$ And courts justify expanded use of informers on the theory that administrative proceedings are not criminal actions and therefore are not governed by the Sixth Amendment. ${ }^{133}$ In reaching this conclusion,

125. E.g., Crenshaw v. United States, 134 U.S. 99 (1890) ; Batiley v. Richardson, 182 F.2d 46 (D.C. Cir. 1950). See Powell, The Right to Work for the State, 16 CoL. L. Rev. 99 (1916) ; Notes, 60 Harv. L. Rev. 779 (1947) ; 6 Rutgers L. Rev. 451 (1952). Cf. Universal Declaration of Human Rights Art. 21.

126. While no court has specifically classified the receipt of a passport as a "privilege" and not a "right," it has been suggested that this is the theory upon which passports have been granted or denied. See Comment, 61 Yale L.J. 171, 187 (1952) ; "Passport Dcnied", 3 Stan. L. Rev. 312, 316 (1951).

127. E.g., State Board of Equalization v. Superior Court, 5 Cal. App. 2d 374, 42 P.2d 1076 (1935) ; Nutler v. State Road Commission, 119 W. Va. 312,193 S.E. 549 (1937). Sec also Tuttrup, Necessity of Notice and Hearing in the Revocation of Occupational Licenses, 4 Wis. L. Rev. 180 (1927).

128. See, e.g., Wright v. Herzog, 182 Md. 316, 34 A.2d 460 (1943) ; Guy v. Utecht, 216 Minn. 255, 12 N.W.2d 753 (1943) ; People v. Oskroba, 305 N.Y. 113, 111 N.E.2d 235 (1953). Contra: Fleenor v. Hammond, 116 F.2d 982 (6th Cir. 1941) ; Brill v. State, 159 Fla. 682, 32 So.2d 607 (1947). See also Weihofen, Revoking Probation, Parole or Pardon Withoul a Hearing, 32 J. CrIM. L. \& CrIMrnology 531 (1942).

129. Milwaukee Publishing Co. v. Burleson, 255 U.S. 407 (1921). But cf. Hannegan v. Esquire, 327 U.S. 146 (1.946) where the Supreme Court cited Justice Brandeis' dissent in the Burleson case and said: "But grave constitutional questions are immediately raised once it is said that the use of the mails is a privilege which may be extended or withheld on any grounds whatever." Id. at 156. And cf. Pike v. Walker, 121 F.2d 37, 39 (D.C. Cir.), cert. denied, 314 U.S. 625 (1941), 50 YALE L.J. 1479.

130. See, e.g.. United States v. MacIntosh, 283 U.S. 605 (1931); Imboden v. United States, 194 F.2d 508 (6th Cir. 1952). Cf. United States v. Cain, 149 F.2d 338 (2d Cir. 1945); De Graw v. Toon, 151 F.2d 778 (2d Cir. 1945).

131. Courts have developed the habit of justifying a refusal to safeguard a "privilege" by mechanically quoting the well-known aphorism of Justice Holmes: "The petitioner may have a constitutional right to talk politics, but he has no constitutional right to be a policeman." McAuliffe v. Mayor and Board of Aldermen of New Bedford, 155 Mass. 216, 220, 29 N.E. 517 (1892). Rarely is an attempt made to determine whether conditions have changed since Justice Holmes dealt with the "rights" of New Bedford policeman.

132. Bailey v. Richardson, 182 F.2d 46 (D.C. Cir. 1950). See also Knauff v. Shaughnessy, 338 U.S. 537 (1950). See Gardner, Bailey v. Richardson and the Constitution of the Utited States, 33 B.U.L. REv. 176 (1953).

The Knauff case involved the application of a wartime measure, 55 STAт. 252 (1941), 22 U.S.C. $\$ 223$ (1946). However, in 1950 Congress provided that the attorney-general could exclude aliens "on the basis of information of a confidential nature, the disclosure of which would be prejudicial to the public interest, safety, or security. . ." 64 STAT. 1006 (1950), 8 U.S.C. § 137-4 (Supp. 1952).

133. Imboden v. United States, 194 F.2d 508 (6th Cir. 1952); Bailey v. Richardson, 182 F.2d 46 (D.C. Cir. 1950). Cf. United States v. Nugent, 200 F.2d 46, 50 (2d Cir. 1952). 
courts rely on the fact that neither the proceedings nor the sanctions imposed are labeled "criminal,"134 nor do administrative bodies in fact follow procedures peculiar to criminal trials. ${ }^{135}$

\section{Assuring Fair Play to Parties}

The subject of an administrative determination, unlike the defendant in a courtroom, derives minimal protection from federal and state constitutions. Due process of law applies only where "rights" are adjudicated. ${ }^{130}$ Here the party involved is afforded an opportunity to meet the case against him; he must receive a full hearing. ${ }^{137}$ This requirement protects a party from an administrative decision based on evidence known only to the deciding body. ${ }^{133}$ However, the hearing guarantee has not necessitated fixed procedural rules;130

See Fraenkel, Can the Administratize Process Erade the Sirth Amendment?, 1 Syrncuse L. REv. 173 (1949).

134. E.g., Fong Yue Ting v. United States, 149 U.S. 698 (1893) (a deportation order is not punishment for crime but a way of enforcing the return to a country by an alien who has not complied with proper procedures); Washington v. Clark, 84 F. Surp. 964, 967 (D.D.C. 1949) (since employer-employee relations are involved, "An employer does not have to grant to his employee a formal trial, with all its pomp and circumstance, before discharging the employee"). Cf. Board of Trade v. Wallace, 67 F.2d 407 (7th Cir. 1933).

135. See, e.g., Carlson v. Landon, 342 U.S. 524, 537 (1952): "Deportation is not a criminal proceeding and has never been held to be punishment. No jury sits. No judicial review is guaranteed by the Constitution." Cf. Helvering v. Afitchell, 303 U.S. 391,400 n.3 (1938).

136. "Due process of law is not applicable unless one is being deprived of something to which he has a right." Bailey v. Richardson, 182 F.2d 46, 58 (D.C. Cir. 1950).

It follows that when a "right" is involved, the proceeding is labeled "adjudicatory" or "judicial." And due process is applicable to "judicial," "quasi-judicial," or "adjudicatory" proceedings. Morgan v. United States, 304 U.S. 1 (193S); Washington v. Clarl, S4 F. Supp. 964 (D.D.C. 1949). But while the procedural requirements of the APA, $\$ \S 7-3$, are applicable only to adjudications "required by statute to be determined on the record after opportunity for an agency hearing," Adarnmstratrve Procenune Act $\$ 5$, the Supreme Court has prescribed similar procedures for adjudications required by the Constitution to be determined after a hearing. Wong Yang Sung v. AfcGrath, 339 U.S. 33 (1950).

However, Congress may prescribe fair procedures for proceedings involving "privileges." An attempt in this directon is found in the Lloyd-LaFollette Act, 37 Srur. 555 (1912), 5 U.S.C. $\$ 652$ (1946), prescribing the manner in which members of the classified Civil Service may be removed.

137. E.g., ICC v. Louisville \& Nashville R.R., 227 U.S. \&\& (1913). See also The Jap3nese Immigrant Case, 189 U.S. 86 (1903).

138. ICC v. Louisville \& Nashville R.R, 227 U.S. \&\&, 93 (1913) ("IT] here is no hearing when the party does not know what evidence is offered or considered and is not given an opportunity to test, explain, or refute."). See also MLoran v. School Commission of Littleton, 317 Mass. 591, 594, 59 N.E.2d 279, 281 (1945) ("A decision made in a quasi-judicial proceeding by an administrative board based on evidence lnown only to members of the board is a nullity."); Thomas J. Meunier's Case, 319 MIass. 421, 66 N.E.2d 198 (1946); Berizzi Co. v. Krausz, 239 N.Y. 315, 146 N.E. 436 (1925). Cf. United States v. Abilene \& Southern R.R., 265 U.S. 274 (1924).

139. See Morgan v. United States, 304 U.S. 1, 19 (1938) : "Congress, in requiring a 'full hearing,' had regard to judicial standards, - not in any technical sense but with respect 
usually there must be notice of charges, ${ }^{140}$ a chance to reply, ${ }^{141}$ and a reasoned decision, ${ }^{142}$ but conformity to the evidentiary rules peculiar to trials is not required. ${ }^{143}$ Consequently, even where "rights" are involved hearsay is freely admissible-determinations need be only in accordance with "reliable, probative and substantial evidence." 144

Parties to an administrative proceeding may, however, be protected from unfair use of hearsay evidence; not all courts agree on whether an administrative decision based entirely on hearsay is valid. ${ }^{\mathbf{1 4 5}}$ And even courts permitting such a decision insist that the hearsay be of the kind "on which responsible persons are accustomed to rely in serious affairs."146 Accordingly, even where the liberal policy toward admitting hearsay is held to permit receipt of reports from unidentified informers, this information cannot form the sole basis of a determination. The widespread condemnation of informers indicates that theirs is not the sort of information upon which responsible persons rely. ${ }^{147}$ An informant may be "a paragon of veracity, a knave, or the village idiot." 148 And where the source of intelligence is known but concealed, suspicion substitutes for certainty.

Moreover, parties before an administrative tribunal are usually permitted to "conduct such cross-examination as may be required for a full and true

to those fundamental requirements of fairness which are of the essence of due process in a proceeding of a judicial nature." See also Davis, An Approach to Problems of Evidence in the Administrative Process, 55 Harv. L. Rev. 364 (1942).

140. Morgan v. United States, 304 U.S. 1, 18 (1938). See also Hurwitz v. North, 271 U.S. 40 (1926) ; Deak v. Pace, 185 F.2d 997 (D.C. Cir. 1950). Cf. Kwong Hai Chew v. Colding, 344 U.S. 590 (1953); Carstens v. Pillsbury, 172 Cal. 572, 158 Pac. 218 (1916).

141. See note 140 supra. See also Bereda Mfg. Co. v. Industrial Board, 275 Ill. 514, 114 N.E. 275 (1916).

142. SEC v. Chenery Corp., 318 U.S. 80, 94 (1943) ("[T] he orderily functioning of the process of review requires that the grounds upon which the administrative agency acted be clearly disclosed and adequately sustained."). See also Administrative Procedure Act $\S 8(\mathrm{~b})$.

143. Opp Cotton Mills v. Adm'n, 312 U.S. 126, 155 (1941). See also Comment, 24 CorN. L.Q. 583 (1939).

144. Administrative Procedure Act \$ 7 (c).

145. See Bridges v. Wixon, 326 U.S. 135, 154 (1945); Consolidated Edison Co. v. NLRB, 305 U.S. 197, 230 (1938); NLRB v. Bell Oil \& Gas Co., 98 F.2d 406, 409 (5th Cir. 1938). The majority of appellate opinons seems to frown upon decisions based entirely on hearsay. See cases collected in Davis, op. cit. supra note 105 , at $\$ 145$.

146. NLRB v. Remington Rand, 94 F.2d 862, 873 (2d Cir.), cert. denied, 304 U.S. 576 (1938). But one court has held that "responsible persons are not accustomed to rely on hearsay in serious affairs." Tyne Co. v. NLRB, 125 F.2d 832, 835 (7th Cir. 1942).

147. "The talebearer shall defile his own soul, and be hated by all." Ecclesiasticus, xxi, 31. See also District of Columbia v. Clawans, 300 U.S. 617, 630 (1937) ; Colyer v. Skeffington, 265 Fed. 17, 69 (D. Mass. 1920), reo'd, 277 Fed. 129 (1st Cir. 1921) ; Bradley v. McIntosh, 5 Ont. Rep. 227 (1884). See statement of Edward Livingston opposing the Alien Bill, quoted in Bowers, JeFFerson AND HaMILTON 378 (1925).

148. Joint Anti-Fascist Refugee Comm. v. McGrath, 341 U.S. 123, 180 (1951.) (concurring opinion). 
disclosure of the facts."149 Some appellate courts have limited the role of informers in administrative proceedings by finding an improper denial of crossexamination. Thus where the report of an informer was admitted in evidence but his identity withheld, courts have found that the denial of opportunity to cross-examine was prejudicial error. ${ }^{150}$ And although courts sanction such a procedure where it is clear that the informer's communication in no way influenced the decision, ${ }^{151}$ they reverse where the communication played sonse part in inspiring a determination. ${ }^{152}$

Where "mere privileges" are being determined, subjects of administrative action are farther removed from constitutional protection. ${ }^{103}$ In fact, the Supreme Court has said that judicial review follows only upon the denial of a "right."154 Until 1952, parties to administrative "privilege" determinations had only hope, based on dicta. ${ }^{155}$ However, in IYicman v. Uipdegraff ${ }^{150}$ the Supreme Court, testing a state loyalty oath program, stated that "constitutional protection does extend to the public servant whose exclusion pursuant to statute is patently arbitrary or discriminatory."16i Justice Clark, for the majority, did not find it necessary first to determine whether one has an "abstract right" to public employment.15s Citizens may find some cheer in this decision; denying a "privilege" on the basis of secret information would seem "patently arbitrary."

But parties to administrative proceedings will not be adequately protected from unfair use of informers' communications so long as many appellate courts

149. Adumistrative Procedune ACT $\$ 7$ (c). See Divis, of cit. sufra note 105 , at 469. See also Philadelphia Co. v. SEC, 175 F.2d S0S, 817 (D.C. Cir. 1948); L. B. Wilson v. FCC, 170 F.2d 793, 805 (D.C. Cir. 1948). Cf. Segal Lock \& Hardware Co. v. FTC, 143 F.2d 935 (2d Cir. 1944).

150. Powhatan Mining Co. v. Ickes, 118 F.2d 105 (6th Cir. 1941). Cf. Simplins v. State Banking Dept., 45 Ariz. 186, 42 P.2d 47 (1935).

151. Kwock Jan Fat v. White, 253 U.S. 454 (1920).

152. Chew Hoy Quong v. White, 249 Fed. 869,870 (9th Cir. 1918) ("IT]here clarly" is no warrant for basing a decision, in whole or in part, on confidential communications."). Cf. United States v. Reimer, 103 F.2d 777 (2d Cir. 1939); United States v. Dunton, 291 Fed. 905 (S.D.N.Y. 1923).

153. See notes $124,131-2$ supra.

154. Perkins v. Lukens Steel Co., 310 U.S. 113 (1940); Dorsheimer v. United States, 74 U.S. 166 (1868).

155. "The Constitution does not guarantee public employment. . . . But it does not at all follow that because the Constitution does not guarantee a right to public employment, a city or State may resort to any scheme for keeping people out of such employment. ... [D] oubtless unreasonable discriminations, if avowed in formal law, would not survive constitutional challenge" Garner v. Los Angeles, 341 U.S. 716, 725 (1950) (concurring opinion). See also United Public Workers v. Mfitchell, 330 U.S. 75, 100 (1947); People v. Crane, 214 N.Y. 154, 168, 108 N.E. 427, 431 (1915).

156. 341 U.S. 183 (1952).

157. Id. at 192. But cf. United States v. Nugent, 346 U.S. 1 (1953). For a discussion of the meaning and significance of the Nugent case, see Brown \& Fassett, supro note 112, at 1194-6.

158. Wieman v. Updegraff, 344 U.S. 1S3, 192 (1952). 
meet them with rubrics and abstract distinctions. No mechanical test has yet been devised to distinguish "rights" from "privileges."150 Where deprivation of a "privilege" inflicts consequences as serious as those entailed by deprivation of a "right," variant procedures are unwarranted. 160 Especially is this so where denial of a "privilege" invades First Amendment guarantees, which supposedly occupy a preferred position in our constitutional framework.101 While a presumption of constitutionality attaches to economic regulations, those affecting First Amendment "rights" of free speech, religion, and press are afforded no such presumption or are presumed invalid. ${ }^{102}$ When the denial of a "privilege" impinges upon such "rights," as where loyalty proceedings throttle free speech, ${ }^{163}$ the "privilege" might well be entitled to exalted protection. ${ }^{164}$

The artificial "right-privilege" dichotomy should not control administrative procedures; that procedure which produces a "fair," "equitable," or "just" result should determine the label. Such a result is not achieved when a person is deprived of a valuable "right" or "privilege" on the basis of information known only to his judges. ${ }^{165}$

159. See Note, 6 Rutgers L. Rev. 451, 459 (1952).

Attempts to distinguish between "rights" and "privileges" have been made. See Houfeld, Fundanental Legal Conceptions cc. 1-2 (1923); Restatemant, Property \$ $\$ 1-2$ (1936); Corbin, Legal Analysis and Terminology, 29 YALE L.J. 163 (1919). But these attempts have been severely criticized. See McDougat \& Haber, Property, Wenttri, Land: Allocation, Planning and Development 28 (1948). For a suggested approach to classification, see Lasswell \& McDougal, Legal Education and Public Policy: Professional Training in the Public Interest, 52 YALE L.J. 203, 237-43 (1943).

160. See Irvine v. State Board of Equalization, 40 Cal. App. 2d 280, 104 P.2d 847 (1940). See Davis, The Requirement of Opportinity to be Heard in the Administrative Process, 51 YaLE L.J. 1093, 1123 (1942); Comment, 61 Y ALE L.J. 171, 190 (1952).

161. See Kovacs v. Cooper, 336 U.S. 77, 82 (1948).

162. United States v. Carolene Products Co., 304 U.S. 144, 152 n.4 (1938). This principle has subsequently been reaffirmed. E.g., Thomas v. Collins, 323 U.S. 516, 529-30 (1944) (" $[T]$ he usual presumption supporting legislation is balanced by the preferred place given in our scheme to the great, the indispensable democratic freedoms secured by the First Amendment.... That priority gives these liberties a sanctity and a sanction not permitting dubious intrusions.").

163. See Judge Edgerton's dissenting opinion in Bailey v. Richardson, $182 \mathrm{~F} .2 \mathrm{~d} 46,66$ (D.C. Cir. 1950). See Jahoda \& Cook, Security Measures and Frcedom of Thonght: An Exploratory Study of the Impact of Loyalty and Security Programs, 61 Y YLE L.J. 295 (1952) ; Comment, 36 Calif. L. Rev. 596, 600 (1948).

164. Bailey v. Richardson, 182 F.2d 46, 71 (D.C. Cir. 1950) (dissenting opinion). See also Emerson \& Helfeld, supra note 118, at 83.

Other legal theories have been utilized to safeguard "privileges." Thus it has been held that a state may not grant a "privilege" under conditions requiring the relinquishment of constitutional rights. Frost \& Frost Trucking Co. v. Railroad Comm'n, 271 U.S. 577 (1925) ; Danskin v. San Diego Unified School Dist., 28 Cal. App. 2d 536, 171 P.2d 885 (1946). See Hale, Unconstitutional Conditions and Constitutional Rights, 35 CoL. L. Rev. 321 (1935); Comment, 39 ILL. L. Rev. 246 (1945).

165. See Justice Frankfurter's concurring opinion in Joint Anti-Fascist Refugee Committee v. McGrath, 341 U.S. 123, 170 (1951): "The heart of the matter is that democracy 
Similarly, distinctions between "rule-making" and "adjudicatory" proceedings are often illusory. ${ }^{106}$ Attempting clearly to define each type of proceeding, no matter how precisely, will not assure uniformly fair decisions. ${ }^{107}$ Frequently situations arise which do not slide comfortably into either slot. An administrative decision may be general in character and apply to the future but may also directly affect the rights of a particular individual. ${ }^{163}$ And every "adjudication" of an individual's rights interprets and declares the law, thus affecting the future conduct of others. ${ }^{169}$ Rubrics are blind to particular justice.

Finally, classification of all administrative determinations as "non-criminal" winks at the gravity of their consequences. Courts label administrative actions non-criminal because they employ non-criminal procedures. ${ }^{170}$ But the procedures prescribed for a particular action are not conclusive of its character. Rather, procedures should follow the nature of the sanction imposed.171 A "criminal" sanction characteristically works deprivation of life, liberty, or property and visits stigma upon the convicted. ${ }^{172}$ Where the severity of an administrative sanction is as great, only a devotion to labels can justify a deviation from Sixth Amendment safeguards. ${ }^{173}$

implies respect for the elementary rights of men, however suspect or unworthy; a democratic government must therefore practice fairness, and fairness can rarely be obtained by secret, one-sided determinations. . . ." Sce also Knauff v. Shaughnessy, 338 U.S. 537, 551 (1950) (dissenting opinion).

166. See Davis, op. cit. supra note 105 , \$54; Parker, The Administralize Pracedture Act: A Study in Overestimation, 60 Y ALE L.J. 581,595 (1951).

167. Davis, op. cit. supra note 105 , at 190 ; Netterville, supra note 123 , at 20 ; Hanlins, The Necessity for Administrative Notice and Hearing, 25 Iowa L. Rev. 457, 463 (1910).

16S. See Philadelphia Co. v. SEC, 175 F.2d 808 (D.C. Cir. 1948), where the cuurt iound that an SEC "rule" so greatly affected the plaintiff's individual rights that classification as adjudication was more accurate and fair.

169. Thus an NLRB decision that certain acts constitute unfair labor practices may prompt an employer or union to change policies presently pursued.

170. See note 135 supra.

171. See Dession, Social Sanctions, 1 VA. L. WeEkly Dicta Cosupilation 22,25 (1949) ; Dession, Sanctions, Law and Public Order, 1 VAvd. L. Rev. 8 (1947).

172. "The distinguishing attribute of the criminal sanction is that whatever other deprivation may be involved (usually liberty and not infrequently property) it also carries a moral stigma. The convict is deprived of respect." Dession, Jtusfice After Corticietion, 25 CoNN. BAR J. 215, 217 (1951).

173. Courts have frequently recognized the severity of administrative sanctions. They have observed that deportation may result in the loss of "all that makes life worth living." Ng Fung Ho v. White, 259 U.S. 276, 284 (1922). The denial of a passport has been viewed as having "a very direct bearing on the applicant's personal liberty" to travel outside of the United States," Bauer v. Acheson, 106 F. Supp. 445, 451 (D.D.C. 1952), especially where her livelihood depended on such travel. In considering what procedures were applicable where a municipal employee was disciplined, the New York Court of Appeals ruled that it made no difference that a disciplinary, rather than a criminal, action was involved. Fusco v. MIoses, 304 N.Y. 424, 107 N.E.2d 581 (1952). And proscription from any opportunity to serve the government has been called "punishment, and of the most severe type." United 


\section{Recommendations and Conclusion}

Appellate courts generally strike a balance between courtroom protection to informers and fair play to parties. Only by allowing perverted testimonial privileges to frustrate the substantive law of defamation and malicious prosecution has the judiciary loaded the scales in favor of informants. ${ }^{174}$ In the administrative process, however, expediency has frequently replaced fairness. Informers' communications are not only used as leads to law violation and misconduct, but also are received as probative evidence. ${ }^{175}$ A party may never know the basis of the administrative tribunal's decision, and the tribunal may not know the source of the reports which guide its determinations. ${ }^{170}$

The administrative process should not provide an opportunity for sidestepping procedural safeguards of individual freedom. Whether or not a particular utilization of informers is constitutional should not be the decisive test; often what escapes constitutional interdiction is nevertheless unwise or unfair. ${ }^{177}$ And it is not too much to ask that administrative procedures be geared to fairness. This does not mean, however, that the government's needs must now be ignored; there is room for compromise in the search for equity. Thus in some circumstances an informer's evidence may properly be employed in an administrative determination without his identity being revealed to the party. ${ }^{178}$ Such a circumstance may arise where the informant, be he an FBI operative or a person in contact with the Bureau, is engaged in counterespionage. Perhaps here the administrative body should be permitted to consider an affidavit from the Director of the FBI which explains the situation, sets forth the informant's evidence, and requests that the informant's identity not be made public. If the administrative tribunal chooses to grant the request, it should nevertheless be told the identity of the informer and be allowed

States v. Lovett, 328 U.S. 303, 316 (1946). The exclusion of an individual from a police force on loyalty grounds "may well ruin his future" and cause him to "suffer . . . blight and humiliation." Hamilton v. Brennan, 203 Misc. 536, 543, 119 N.Y.S.2d 83, 89 (Sup. Ct. 1953). And the Supreme Court has also noted the consequences of being labeled "disloyal." Wieman v. Updegraff, 344 U.S. 183, 191 (1952).

174. See text at pp. 216-20 supra.

175. See notes 109-110 supra.

176. See note 117 supra.

177. "Civil liberties draw at best only limited strength from legal guaranties. Preoccupation by our people with the constitutionality, instead of with the wisdom, of legislation or of executive action is preoccupation with a false value. ... Focusing attention on constitutionality tends to make constitutionality synonymous with wisdom." Frankfurter, J., concurring in Dennis v. United States, 341 U.S. 494, 555 (1951). See also BidDLE, THE FEAR of FreEdon 212 (1952) ; Chafee, Thirty-Five Years with Freedom of Spccch, 1 KAN. L. Rev. 1, 27 (1952) ; Durr, The Loyalty Order's Challenge to the Constitution, $16 \mathrm{U}$. of Cin. L. REv. 298, 305 (1949).

178. The recommendations following in the text apply only to those administrative proceedings currently said to involve "privileges" or to be concerned with "rule-making" functions. 
to cross-examine him at an in camera session.170 The general nature of the informer's testimony should be revealed to the party involved, ${ }^{189}$ and the party should be permitted to supplement the agency's examination with written interrogatories. However, if the agency perceives that its decision will necessarily rest solely on the informant's testimony, his identity should be disclosed to the party or the proceeding should be dropped. Where the informer is not a counter-espionage agent, the government should either present the informer, forego use of his evidence, locate evidence which it feels free to submit unconditionally, or abandon the case. ${ }^{1 \mathrm{~s} 1}$

But perhaps the pressing need for adjustment in the use of informers should prompt a general reconsideration of their place in a democratic society ${ }^{182}$ a society whose peculiar wisdom has been its respect for the individual. 183 The informer has not been an honored member of the community ; 182 protecting him by depriving a party of fair play frequently means that slight risks to national security have been avoided by permitting very great risks to individual rights. ${ }^{185}$ Yet "every adherence to our moral professions reinforces our strength and therefore our security." 180 The value of informers should be compared with the harms attending their utilization, to the end that

179. Cf. Shaughnessy v. United States $c x$ rel. Mezei, 345 U.S. 205, $228 \mathrm{n} .9$ (1953).

180. Cf. Donovan \& Jones, Program For a Denocratic Counter Altacl: to Conmusist Penetration of Government Sericie, 58 Yale L.J. 1211, 1235 (1949); Note, 47 CoL. L. Rev. 1161,1176 (1947).

181. Cf. Brown \& Fassett, supra note 112, at 1201-3.

182. "The use of statements by informers who need not confront the person under investigation or accusation has such an infamous history that it shuuld be rooted out from our procedure. A hearing at which these faceless people are allowed to present their whispered rumors and yet escape the test and torture of cross-examination is not a hearing in the Anglo-American sense. We should be done with the practice-whether the life of a man is at stake, or his reputation, or any matter touching upon his status or his rights. If FBI reports are disclosed in administrative or judicial proceedings, it may be that valuable underground sources will dry up. But that is not the choice. If the aim is to prutect the underground of informers, the FBI report need not be used. If it is used, then fairness requires that the names of the accusers be disclosed. Without the identity of the informer the person investigated or accused stands helpless. The prejudices, the credibility, the passions, the perjury of the informer are never known. If they were exposed, the whole charge might wither under the cross-examination." Douglas, J., dissenting in United States v. Nugent, 346 U.S. 1, 13 (1953). See also O'Reilly, Discozery Against the United Stotes: A Ncw Aspect of Sovereign Inmmutity, 21 N.C.L. REv. 1, 14 (1942).

183. Barth, The Loyalty of Free Mien 3 (1951); Douglas, A Crusude for the Bar: Due Process in a Time of World Conflitt, 39 A.B.A.J. 871, 875 (1953).

184. See note 147 supra.

185. Carr, National Security and Indiridual Frecdon, 42 YALE Rev. 490, 497 (1953); "Lawyer Schools" or "Policy Scicalce"?: Yale Law Faculty's Manifcsto Stirs Debate, 34 A.B.A.J. 15 (1948). But cf. Hoover, A Comment on the Article "Loyalty Anong Gonisn:ment Entoloyees, 58 YALE L.J. 401,409 (1949).

186. Frankfurter, J., dissenting in United States v. Nugent, 346 U.S. 1, 13 (1953). 
their true worth may be assessed.187 In this endeavor the words of Judge Learned Hand must figure: "Risk for risk, for myself I had rather take my chance that some traitors will escape detection than spread abroad a general suspicion and distrust, which accepts rumor and gossip in place of undismayed and unintimidated inquiry. I believe that that community is already in process of dissolution where each man begins to eye his neighbor as a possible enemy...."188

187. Note that assurance of anonymity may not be the only effective device for encouraging communications to the government. The policy of affording protection to informers developed side by side with a conflicting policy : qui tam actions gave the informer an opportunity to reap a reward for his sleuthing. Donnelly, Judicial Control of Informants, Spies, Stool Pigeons, and Agents Provocateurs, 60 YALE L.J. 1091 (1951). This action was first permitted under the customs law but is now also granted in many other fields. IVid. For a discussion of informer suits see United States v. Hess, 317 U.S. 537 (1943). Accordingly, persons who detect violations of these laws are allowed to bring a suit and recover part of the penalty imposed by law. Thus informers can currently choose between two courses of action: to the bold, notoriety and financial gain are assured; to the timid, anonymity is profferred.

188. Address by Judge Learned Hand at the 86th Convocation of the University of the State of New York, Oct. 24, 1952, at Albany, New York. 